\title{
Ecological Health Evaluation of Ziarat River Using Water Quality Index, Golestan Province, Iran
}

\author{
Elham Mirrasooli ${ }^{*}$, Rasoul Ghorbani ${ }^{1}$, Masoud Molaei $^{2}$ \\ ${ }^{1}$ Department of Fisheries, Gorgan University of Agricultural Sciences and Natural Resources, Gorgan, Iran \\ ${ }^{2}$ Department of Fisheries and Environmental Science, Gonbad University of Agricultural Sciences and Natural Resources, \\ Gonbad, Iran \\ Email: *elhammirrasooli@gmail.com
}

How to cite this paper: Mirrasooli, E., Ghorbani, R. and Molaei, M. (2017) Ecological Health Evaluation of Ziarat River Using Water Quality Index, Golestan Province, Iran. Open Journal of Ecology, 7, 631-639. https://doi.org/10.4236/oje.2017.713043

Received: October 11, 2017

Accepted: December 18, 2017

Published: December 21, 2017

Copyright (c) 2017 by authors and Scientific Research Publishing Inc. This work is licensed under the Creative Commons Attribution International License (CC BY 4.0).

http://creativecommons.org/licenses/by/4.0/

\section{cc (i) Open Access}

\begin{abstract}
Due to decreasing water quality of the Ziarat River, which is one of the most important rivers for drinking water in Gorgan, it is necessary to manage this river. The purpose of this study was to evaluate the ecological health of the Ziarat River of Golestan province via the Water Quality Index (WQI) qualitative index. For this purpose, 6 sampling stations were selected along the Ziarat River, and samples were taken from April to August of 2014 every 45 days at sampling stations. The parameters of dissolved oxygen, nitrate, nitrite and phage were measured at each turn and the data were analyzed by WQI qualitative index and SPSS 21 software. The results showed that water quality of the Ziarat River was relatively good during the spring and summer. Also, the results showed that there was a significant correlation between nitrite and positive qualitative index (with increasing amount of nitrite the numerical value of the qualitative index also increases, which indicates a decrease in water quality). Between the dissolved oxygen and the numerical value of the negative quality correlation index (with increasing amount of solution oxidant, the numerical value of the qualitative reduction index, which indicates the increase of water quality).
\end{abstract}

\section{Keywords}

Water Quality Index, Ziarat River, Physical and Chemical Parameters

\section{Introduction}

Monitoring the quality of rivers due to the recent drought and urban and rural development is one of the important tasks in the field of environmental management 
[1]. Rivers' water quality depends on various conditions including hydrological, physicochemical and biological processes. Water resources have significant impact on social, economic and political developments. Having healthy water resources is an essential prerequisite for environmental protection while surface water is more prone to pollution than other water sources. These resources are very important in terms of social, economic and political development providing [2]. Safe water is one of the basic requirements for the life of human beings, which requires quality control by means of laboratory tests and different indices for controlling it. Therefore, river health assessment can be used as a tool for estimating the water flow quality required for the survival of river ecosystems, and monitoring and continuous monitoring of water quality are considered as the main tools for management and conservation of these valuable resources [3]. One of the very simple methods without mathematical and statistical complexity can describe the qualitative conditions of water and as an advanced tool strong for relevant decisions, use of indicators quality water. Water Quality Indicators are the ways in which Water quality management, can be simplified and reduced information Raw, in addition to expressing water quality, the process of water quality changes during checking the location and time, and the areas that are most contaminated Threatening, identifying and managing [4]. Due to the entry of various pollutants into aquatic ecosystems which, in addition to ecological values, are also of high economic importance, their health value is of great importance [5]. The most important aquatic ecosystems are freshwater rivers, which are considered as biodiversity and drinking water. In this regard, the quantitative and qualitative study of these resources is an important pillar of sustainable development [6]. Quantitative and qualitative changes in physical and chemical properties of water indicated the presence of contamination in ecosystems [7]. And since our country is facing limited water resources and is considered a low-water country, it is inevitable to know the quality of available water resources for their proper management [8]. Ghorbani et al. (2015) [2] assessed the health status of the Ziarat Stream based on NSFWQI quality index (Golestan Province). The result showed that the best situation was related to first station (Ziarat waterfall) in June month and the worst situation was related to 5 stations (The most important tourist center) in April. As for present results, quality condition of Ziarat Stream was unsuitable: Salari et al. (2013) Quantitative and Qualitative Assessment of Karoon River Water Using National sanitation foundation water quality index (NSFWQI) and Analytic hierarchy process (AHP) Method. Subsequently, the nine present NSF parameters' weights have been changed and modified using the analytical hierarchy process (AHP) method as well as experts' opinions in the field in a way to satisfy local conditions [1]. Also ecosystem health assessment of the Liao River Basin upstream region based on ecosystem services and the result showed that different stations in this ecosystem were different in terms of health. In general, it can be argued that western ecosystems had better health than the eastern regions. Therefore, management should be done to protect the eastern regions [6]. Therefore, it can 
generally be stated that due to the increased utilization of river surface resources and the reduction of the flow due to reduced rainfall, climate change and increased pollution. Assessment of river health in different regions of the country and knowledge of the quality of water resources in conservation, planning and management of these resources is very important and from where that the WQI (Water Quality Index) is an attempt to provide a general response to water quality. Therefore, the purpose of this study is to evaluate the ecological health of Ziarat River in Golestan province using the WQI index.

\section{Materials and Methods}

\subsection{Describing the Area under Study}

Ziarat River with an area of 9873 hectares is one of the sub-basins of the Ghareh Sou river, located in south of Gorgan. The basin is in the (54 23 -minute and 55 -second) intervals to (54 31', 10 seconds) east longitude and (36 degrees 36 minutes and 58 seconds) to (36 degrees 46 minutes and 11 seconds) north latitude. Sampling stations along the river route were determined based on factors such as elevation, slope, bedding, and water flow rate and land use type of marginal land.

\subsection{Sampling Procedures}

In this study, six sampling stations were selected and samplings took place from April to August 2014 every 45 days (According to the sampling of water resources of the Water and Wastewater Company of Iran, which can be done monthly for sampling 45 days). Samples were taken in duplicate at the same hour of the day throughout the study. Sampling stations along the river route were determined based on factors such as the location of the settlements, industrial areas, access roads, altitudes, slopes, bedding, water flow rate and land use type of marginal land. In this study physiochemical characteristics and nutrients of water, including $\mathrm{DO}(\mathrm{mg} / \mathrm{L})$ and $\mathrm{pH}(\mathrm{mg} / \mathrm{L})$ were measured with Wagtech Laboratory (Model Photometer 7100) and nitrate and nitrite (mg/l) were measured using a spectrophotometer in the laboratory.

\subsection{Calculating WQI Indicator}

Water Quality Index (WQI) was calculated using 4 parameters of nitrite, nitrate, dissolved oxygen and phage. In the interpretation of the results of this index, it is assumed that with increasing pollution, the WQI quality index also increases, which indicates an increase in pollution and a decrease in water quality

To calculate this index, 4 parameters including nitrate, nitrite, dissolved oxygen and $\mathrm{pH}$ were used. Then the required values for calculating the index were calculated based on the following relationships [9].

$$
\mathrm{RW}=\mathrm{AW} / \sum \mathrm{AW}
$$

RW1 $=$ Weight ratio of each parameter (Table 1$)$

AW2 = is the weight assigned to each parameter, which is based on expert 
Table 1 . The weight ratio of water quality parameters [11].

\begin{tabular}{cccc}
\hline Parameters & RW & AW & Standard drinking water WHO.2004 \\
\hline $\mathrm{NO}_{2}(\mathrm{mg} / \mathrm{l})$ & $0 / 141,844$ & 2 & 30 \\
$\mathrm{NO}_{3}(\mathrm{mg} / \mathrm{l})$ & $0 / 156,028$ & 2.2 & 50 \\
$\mathrm{DO}(\mathrm{mg} / \mathrm{l})$ & $0 / 283,688$ & 4 & 5 \\
$\mathrm{pH}$ & $0 / 148,643$ & 2.1 & $6 / 5-8 / 5$ \\
\hline
\end{tabular}

Table 2. Weight assigned to each parameter in different sources and their mean [11].

\begin{tabular}{ccccc}
\hline Research & $\mathrm{PH}$ & $\mathrm{DO}(\mathrm{mg} / \mathrm{l})$ & $\mathrm{NO}_{3}(\mathrm{mg} / \mathrm{l})$ & $\mathrm{NO}_{2}(\mathrm{mg} / \mathrm{l})$ \\
\hline Abrahão et al., 2007 & 1 & 4 & 2 & 2 \\
Boyacioglu, 2007 & 1 & 4 & 3 & \\
Chougule et al., 2009 & 4 & 4 & & \\
Dwivedi and Pathak, 2007 & 4 & 4 & & 2 \\
Kannel et al., 2007 & 1 & 4 & 2 & 2 \\
Karakaya and Evrendilek, 2009 & 1 & 4 & 2 & 2 \\
Pathak and Banerjee, 1992 & 4 & 4 & & 2 \\
Pesce and Wunderlin, 2000 & 1 & 4 & 2 & 2 \\
Mean & $2 / 1$ & 4 & & 2 \\
\hline
\end{tabular}

opinion in previous studies (Table 2) (Fathi, 2011) [10].

$$
\begin{gathered}
\mathrm{Qi}=(\mathrm{Ci} / \mathrm{Si}) * 700 \\
\mathrm{Qi}=(\mathrm{Ci}-\mathrm{Vi} / \mathrm{Si}-\mathrm{Vi}) * 700
\end{gathered}
$$

In Equations ((2) and (3)): Qi: the quality level; Ci: the amount obtained from each parameter in the laboratory; Si: reported in the global standard for drinking water, Vi: The optimal value for $\mathrm{pH}$ is 7 and for $\mathrm{DO}$ it is equal to $14 / 6$. The weight assigned to each parameter and mean used is given in Table 2. Finally, to calculate the WOI, the SLI subcategory was first calculated for each parameter (Equation (4)) and from the total SLIs, the numerical value of WQI was estimated (Equation (5)).

$$
\begin{gathered}
\mathrm{SIi}=\mathrm{RW}^{*} \mathrm{Qi} \\
\mathrm{WQI}=\sum \mathrm{WiQi}
\end{gathered}
$$

Using Equation (5), the Water Quality Index (WQI) was calculated at different stations and samplings. Finally, the water quality status at stations and different samplings was determined based on the general classification of WQI water quality index (Table 3).

\subsection{Statistical Methods}

SPSS21 software was used to determine the data normality and correlation coefficient between parameters. The SPSS software was used to analyze data. All parameters were normal according to Kolmogorov Smirnov test. The $\mathrm{P}<0.05$ 
Table 3. Qualitative classification of natural waters based on the overall score of the WQI index [12].

\begin{tabular}{cc}
\hline Qualitative class & The value of the obtained index \\
\hline Unsuitable & 300 \\
Very poor & $200-300$ \\
Poor & $100-200$ \\
Good & $50-100$ \\
Excellent & $<50$ \\
\hline
\end{tabular}

Table 4. Parameters measured at sampling stations (mean \pm SD).

\begin{tabular}{ccccc}
\hline Stations & $\mathrm{NO}_{2}(\mathrm{mg} / \mathrm{l})$ & $\mathrm{NO}_{3}(\mathrm{mg} / \mathrm{l})$ & $\mathrm{DO}(\mathrm{mg} / \mathrm{l})$ & $\mathrm{pH}$ \\
\hline 1 & $0.06 \pm 0.1^{\mathrm{a}}$ & $1.65 \pm 0.18$ & $14.41 \pm 3.11^{\mathrm{a}}$ & $8.57 \pm 0.08^{\mathrm{a}}$ \\
2 & $0.03 \pm 0.00^{\mathrm{b}}$ & $1.57 \pm 0.06$ & $11.81 \pm 1.6^{\mathrm{b}}$ & $8.53 \pm 0.08^{\mathrm{a}}$ \\
3 & $0.03 \pm 0.00^{\mathrm{b}}$ & $1.44 \pm 0.06$ & $1.00 \pm 1.3^{\mathrm{b}}$ & $8.11 \pm 0.03^{\mathrm{b}}$ \\
4 & $0.03 \pm 0.00^{\mathrm{b}}$ & $1.47 \pm 0.04$ & $10.78 \pm 0.6^{\mathrm{b}}$ & $8.32 \pm 0.07^{\mathrm{ab}}$ \\
5 & $0.03 \pm 0.00^{\mathrm{b}}$ & $1.62 \pm 0.05$ & $10.37 \pm 0.6^{\mathrm{b}}$ & $8.41 \pm 0.04^{\mathrm{ab}}$ \\
6 & $0.02 \pm 0.00^{\mathrm{b}}$ & $1.62 \pm 0.05$ & $9.57 \pm 0.8^{\mathrm{b}}$ & $8.33 \pm 0.06^{\mathrm{ab}}$ \\
Mean & 0.03 & 1.56 & 11.38 & 8.37 \\
\hline
\end{tabular}

was used as significance level used for data evaluation. One-way ANOVA was employed to analyze data. Then, means were compared by Tukey's test.

\section{Results}

The results of measuring the physicochemical parameters of water at different sampling stations are given in Table 4.

Significant differences were observed in some of the measured parameters between different sampling stations $(P<0.05)$. Based on the findings of the 6 sampling stations, it can be stated that the numerical value of the quality index The WQI did not make a significant difference between the sampling stations. The maximum WQI quality index at station 1 was 61.56 and the minimum amount was at station 4 with 51/81 (Table 5).

According to Figure 1 and Table 3, the observed differences in the qualitative index between the sampling stations are quantitative and statistical and are within range (50 to 100) and are not excluded from this range, indicating that sampling stations during the time of the present research it has a good quality. In general, it can be stated that according to the results obtained, the water quality of the Ziarat River in the province of Golestan is in good class in terms of time and is suitable for human consumption and drinking purposes.

\section{Data Correlation}

Regarding the data are normal, the data from the calculations performed in this study were used to verify the correlation between the physico-chemical parameters 
Table 5. WQI index values calculated at different sampling stations (mean $\pm \mathrm{SD}$ ). There was no significant difference in WQI between sampling stations $(p \geq 0.05)$.

\begin{tabular}{cc}
\hline Stations & Water Quality Index \\
\hline 1 & $61.56 \pm 12.06$ \\
2 & $60.51 \pm 2.81$ \\
3 & $55.21 \pm 4.19$ \\
4 & $51.81 \pm 3.81$ \\
5 & $53.49 \pm 2.19$ \\
6 & $52.41 \pm 1.14$ \\
\hline
\end{tabular}

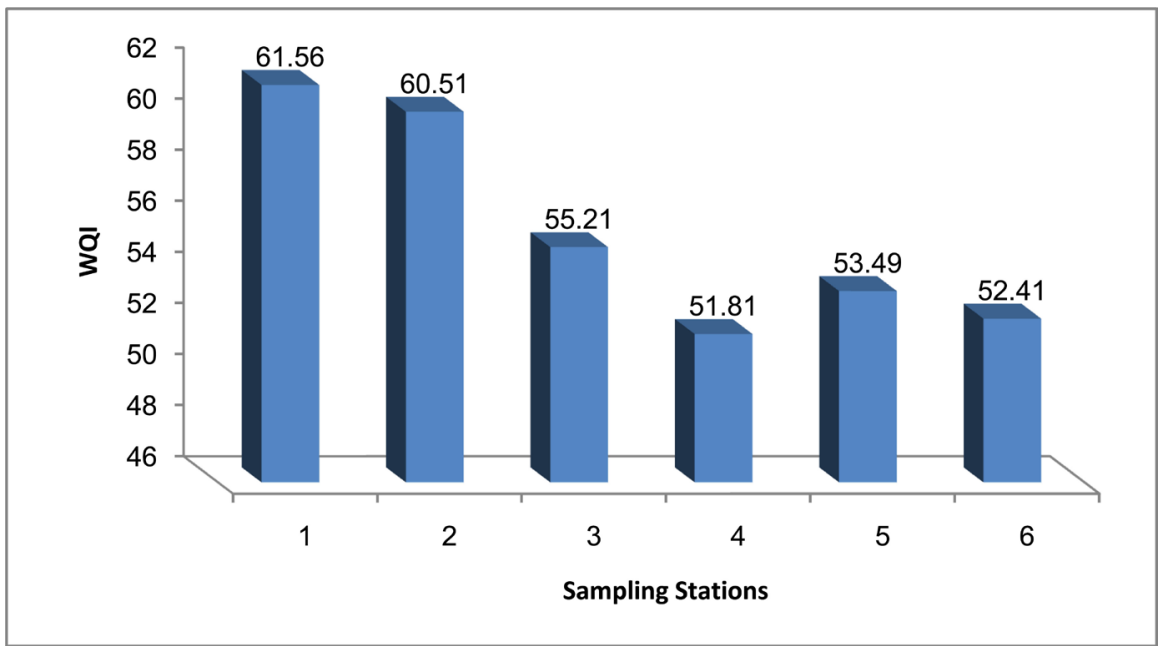

Figure 1. Average WQI water quality index at the stations studied.

Table 6. Correlation between Water Quality Parameters and WQI Quality Index at Study Stations (Significant at $1 \%$ ).

\begin{tabular}{cccccc}
\hline WQI & $\mathrm{PH}$ & $\mathrm{DO}(\mathrm{mg} / \mathrm{l})$ & $\mathrm{NO}_{3}(\mathrm{mg} / \mathrm{l})$ & $\mathrm{NO}_{2}(\mathrm{mg} / \mathrm{l})$ & \\
\hline 1 & $0 / 358$ & $-0 / 821^{*}$ & $0 / 588$ & $0 / 481^{*}$ & WQI \\
\hline
\end{tabular}

and WQI water quality index from Pearson correlation coefficient. The results of correlation coefficients are shown in Table 6. The results showed that there was a significant correlation between the parameters of nitrite and dissolved oxygen with the qualitative index between the quality index and the measured parameters at different sampling stations. This correlation between nitrite and positive qualitative index (with increasing amount of nitrite The numerical value of the qualitative index also increases, which indicates a decrease in water quality. Between the dissolved oxygen and the numerical value of the negative quality correlation index (with increasing amount of solution oxidant, the numerical value of the qualitative reduction index, which indicates the increase of water quality) was observed (Table 6).

\section{Discussion and Conclusion}

Based on the findings of the present study, there was no significant difference in 
the nitrate level of the Ziarat River in Golestan province at different stations. The average amount of nitrate in the river water was $1.65 \mathrm{mg} / \mathrm{L}$, which was reported as the amount of nitrate in surface water based on available resources and environmental standards was $1 \mathrm{mg} / \mathrm{l}$ [13]; more it has been the standard of the environment. It can be stated that the causes of nitrate entry into the river water are human activities around the river and the influence of waste water from agriculture and home. On the other hand, the nitrite content of the Zilat River in Golestan province was significant at the station and the mean nitrite in the river water was equal to $03 / 0 \mathrm{mg} / \mathrm{L}$. Considering that the amount of nitrite in surface water based on available resources and environmental standards should not be higher than $0.51 \mathrm{mg} / \mathrm{L}$ being reported (EPA, 1994) [13] in the environmental standard. In confirmation of these results, it can be noted that Kazhi et al. (2009) [14] reported nitrate, nitrite, phosphate and ammonium nitrate levels in Lake Manchar, Pakistan, due to the influence of domestic wastewater and fertilizers used in the agricultural sector. Lodh et al. in 2014, [15] on the Indian Ocean Lake Anset, nitrate was regarded as the main nutrient for the growth of algae and phytoplankton, and its concentration could be affected by the fluctuation of plankton. The measured $\mathrm{pH}$ during the sampling time at the station was an average of 8.37, located in the alkaline range. This factor plays a significant role in the health and fertility of water and plays an important role in evaluating water quality. The mean phage in the stations studied in this study conformed to the standards of Iran and the world. It is worth noting, however, that the $\mathrm{pH}$ of the ecosystems is derived from geological and hydrological properties of the watersheds, the input of acidic substances and the level of lake fertility. The dissolved oxygen content at all stations was 11.38 on average, with a maximum at station 1 and a minimum amount at station 6 , except for the station, one of the remaining stations had a steady trend.

The amount of oxygen dissolved depends on factors such as water temperature (with increasing water temperature, reduced oxygen dissolution), vital activities such as respiration and organic matter decomposition (increasing vital activity of reducing oxygen dissolution). The effect of oxygen on water quality is very influential and can have a significant effect on its color, taste and smell. The results of the changes in dissolved oxygen are consistent with the results of Gajendra et al. [16]. The results showed that water quality of the Ziarat River, despite the decrease in spring and summer, was in good condition (between 50 - 100). Khalaji et al., in 1395, evaluated the water quality of Lake Zayandehrood dam using the WQI index and the sign they said that water quality is in good condition and that care should be taken to maintain water quality. Amin Pourshiani et al. (2015) [17] evaluated the water quality of Gharbroodbar River using the NSFWQI qualitative index and Liou pollution index. According to the results of this study, the monthly average of the NSFWQI index is in the range of 50 50.50 and the monthly average of Liou index ranges from 1.1 to 3.85. Based on these indices, the No. 1 station was of the best quality and the No. 4 station had the worst quality. According to the NSFWQI index, Rudbar gas is ranked in 
the middle class (70 - 50) and based on the Liou index in a slightly polluted class (2 - 3). Ghorbani et al. (2015) [2] to assessment of the health status of the Ziarat Stream based on NSFWQI quality index (Golestan Province). The result showed that the best situation was related to first station (Ziarat waterfall) in Joun month and the worst situation was related to 5 stations (The most important tourist center) in April. As for present results quality condition of Ziarat Straem was unsuitable. Salari et al. (2013) [1] performed Quantitative and Qualitative Assessment of Karoon River Water via NSFWQI Index and AHP Method. Subsequently, the nine present NSF parameters' weights have been changed and modified by the analytical hierarchy process (AHP) method as well as experts' opinions in the field in a way to satisfy local conditions Yan et al. (2016) [6] Ecosystem health assessment of the Liao River Basin upstream region based on ecosystem services and the results showed that there were significant spatial differences in ecosystem health in this region. In general, the west regions were better than the east, ecosystem health of regions in descending order is as follows: Laoha River sub-basin NXiliao River sub-basin, and Xila Mulun River sub basin N Xinkai River sub-basin. The eastern ecosystems had less health than western ecosystems. Also in the sub-basins, more health was observed than branching sub-basins. Generally, based on the results obtained, it can be stated that the qualitative conditions of the passage of undesirable pilgrimage were introduced. In general, it can be said that according to the results of the present research and their comparison with the water quality standards in Iran and the world, water of the Ziarat River of Golestan province during the period of this research was in terms of quality in good and acceptable conditions. And has the ability to use for human consumption, including drinking. However, due to the changes in the WQI index and the beginning of its exit from the good quality waters, reducing the river's water volume in summer, the dramatic increase of tourism use at the river's margin, uncooperative land use changes in the watershed, etc. Precise and continuous assessments of water quality in this river are necessary.

\section{References}

[1] Salari, M., Feridon, R. and Zarei, H. (2013) Quantitative and Qualitative Assessment of Karoon River Water Using NSFWQI Index and AHP Method. Human and Environmental Journal, 10, 13-22.

[2] Ghorbani, R., Hajimoradlou, A., Molayi, M., Naeimi, A., Norozi, N. and Vesaghi, M. (2015) Assessment of the Health Status of the Ziyarat Stream Based on NSFWQI Quality Index (Golestan Province). 4, 111-122.

[3] Khoroshi, S., Mostafa Zadeh, R., Esmaili Ouri, A. and Rauf, M. (2016) Estimation of Temporal and Spatial Variations of Hydrologic Index of River in Watersheds of Ardabil Province. Echo Hydrology, 4, 379-393.

[4] Pinto, U., Maheshwari, B.L., Sherestha, S. and Morris, C. (2012) Understanding the Meaning of River Health for a Community: Perspectives from the Peri-Urban Region of the Hawkesbury-Nepean Catchment, Australia. Water Policy, 14, 766-783. https://doi.org/10.2166/wp.2012.074 
[5] Park, Y.-S. and Chon, T.-S. (2015) Editorial: Ecosystem Assessment and Management. Ecological Informatics, 29, 93-95. https://doi.org/10.1016/j.ecoinf.2015.05.003

[6] Yan, Y., Zhao, C.L., Wang, C.X., Shan, P., Zhang, Y.J. and Wu, G. (2016) Ecosystem Health Assessment of the Liao River Basin Upstream Region Based on Ecosystem Services. Acta Ecologica Sinica, 36, 294-300. https://doi.org/10.1016/j.chnaes.2016.06.005

[7] Asiabi-Hir, R., Mostafazadeh, R., Raoof, M. and Esmali-Ouri, A. (2016) Water Poverty Index and Its Importance in Water Resources Management. Extension and Development of Watershed Management, 3, 17-22.

[8] Sharifinia, M. (2012) Benthic Macroinvertabrate Distribution in Tajan River Using Canonical Correspondence Analysis. Caspian Journal of Environmental Sciences, 10, 181-194.

[9] Brown, R.M., McClellan, N.I., Deininger, R.A. and Tozer, R.G. (1970) A Water Quality Index-Do We Dare? Water Sew Works, 117, 339-343.

[10] Fathi, P. (2013) Assessment of Water Quality in Choghakhor Wetland by Using Large Bulk Fertilizers. Master's End, 80 p.

[11] Khalaji, M., Ebrahimi, E., Motaghe, E., Asadola, S. and Hashemenejad, H. (2017) Water Quality Assessment of the Zayandehroud Lake Using WQI Index. ISFJ, 25, 51-63. http://isfj.ir/article-1-1545-fa.html

[12] Ramakrishnaiah, C.R., Sadashivaiah, C. and Ranganna, G. (2009) Monitoring of Aquatic Macroinvertebrates as Bioindicator for Assessing the Health of Wetlands. Ecological Indicators, 9, 118-128. https://doi.org/10.1016/j.ecolind.2008.02.004

[13] EPA (1996) Quality Criteria for Waters. Washington DC.

[14] Kazi, T.G., Arain, M.B., Jamali, M.K., Jalbani, N., Afridi, I., Sarfraz, R.A., Baig, J.A. and Shah, A.Q. (2009) Assessment of Water Quality of Polluted Mlake Using Multivariate Statistical Techniques: A Case Study. Ecotoxicology and Environmental Safety, 72, 301-309. https://doi.org/10.1016/j.ecoenv.2008.02.024

[15] Lodh, R., Paul, R., Kurmakar, B. and Das, M.K. (2014) Physicochemical Studies of Water Quality with Special Reference to Ancient Lakes of Udaipur City, Tripura, India. International Journal of Scientific and Research Publication, 42, 2250-2315.

[16] Gajendra, R., Swapnaja, S. and Smita, M. (2014) Monthly Variation of Physicochemical and Microbiological Characteristics of Sambhaji Lake Solapur, Maharashtra. Advances in Applied Science Research, 5, 149-152.

[17] Aminpour Shiani, S. Mohamadi. M., Khaledian, M. and Mirroshandel, A. (2016) Water Quality Evaluation of Gazroudbar River Using NSFWQI and Liou Indices. Wetland Ecobiology, 8, 63-74. http://jweb.iauahvaz.ac.ir/article-1-407-fa.html 